\title{
中枢神経系原発リンパ腫アップデート
}

\author{
山崎 文之 \\ 広島大学病院脳神経外科
}

\section{Primary Central Nervous System Lymphoma : An Update}

\author{
Fumiyuki Yamasaki, M.D., Ph.D. \\ Department of Neurosurgery, Hiroshima University Hospital
}

Primary central nervous system lymphoma (PCNSL) develops more often in the elderly population. Its incidence has been increasing in recent years and it is accounting for $4.9 \%$ of brain tumors. Most PCNSLs are histologically classified as diffuse large B-cell lymphomas. Among these, CD10 positivity is lower and MUM1 positivity is higher in PCNSL than in non-PCNSL, which results in higher dominance of the nongerminal-center B-cell-like type in PCNSLs. The frequency of mutations in MYD88 and CD79B genes is higher in PCNSL than in non-PCNSL, which leads to the activation of the B-cell-receptor signaling pathway. Bruton's tyrosine kinase (BTK) is a key molecule in the B-cell-receptor signaling pathway. Therefore, it is a potential molecular target for the treatment of PCNSL. Tirabrutinib, a second-generation BTK inhibitor, has been developed and approved in Japan for the treatment of recurrent or refractory PCNSL. Current challenges include increasing the intensity of chemotherapy while reducing the dose or avoidance of whole-brain radiotherapy (WBRT), as brain damage and late effects, including leukoencephalopathy, are not negligible not only in elderly patients but also in young patients. In Japan, the combination of rituximab, high-dose methotrexate, procarbazine, and vincristine, the so-called R-MPV therapy, is being recognized as a new standard induction chemotherapy. R-MPV therapy followed by reduced-dose WBRT and high-dose cytarabine is well tolerated and shows better outcomes than the previous standard high-dose methotrexate therapy followed by WBRT. High-dose chemotherapy with autologous peripheral blood stem cell transplantation in young patients and appropriate treatment selection at the time of recurrence are essential for further improvement of treatment outcomes.

(Received July 15, 2021 ; accepted August 4, 2021)

Key words : primary central nervous system lymphoma, diffuse large B cell lymphoma, whole brain radiotherapy, R-MPV, tirabrutinib

Jpn J Neurosurg（Tokyo）31:20-30, 2022

\section{はじめに}

悪性リンパ腫は，全身のリンパ節や中枢神経系原発リ

ンパ腫 (primary central nervous system lymphoma:

PCNSL）のようにリンパ節外から発生するリンパ球由来
の悪性腫瘍の総称である. PCNSL は診断時に脳・春髄と 眼内の中枢神経以外の部位に病変を認めないリンパ腫の 亜型と定義される。PCNSL は脳以外の部位に発生した リンパ腫と比較して, 生命予後が不良である ${ }^{11)}$. PCNSL は組織型分類ではほとんどが非ホジキンリンパ腫の成熟

連絡先：山崎文之， $\overline{\mathbf{T}} 734-8551$ 広島市南区霞 1-2-3 広島大学病院脳神経外科

Address reprint requests to : Fumiyuki Yamasaki, M.D., Ph.D., Department of Neurosurgery, Hiroshima University Hospital, 1-

2-3 Kasumi, Minami-ku, Hiroshima-shi, Hiroshima 734-8551, Japan 
型 $\mathrm{B}$ 細胞リンパ腫の中のびまん性大細胞型リンパ腫 (diffuse large B cell lymphoma：DLBCL) で, DLBCL の中の 分類では「その他」に含まれる。 DLBCLの組織型の中の 比較でも PCNSL の生命予後は不良である ${ }^{11)}$. PCNSL の 治療成績としては, 米国では生存期間中央值が 1990 年 代以前の 12.5 14 力月と比べ, 2000 年代では 18 力月, 2010 年代では 26 カ月と年々向上しているが22), ス ウェーデンでは, 2000 年代以降に変化していないと報告 されている ${ }^{10)}$. 本邦においては, 照射前大量メトトレキ サート療法（high dose methotrexate：HD-MTX）とそれ に引き続いた全脳放射線治療 (whole brain radiotherapy： WBRT), 残存がある場合はさらに局所に追加照射を行 うことが標準治療として認識され, 広く用いられてき た。 そして欧米の良好な多剤併用療法の結果や分子標的 薬のリツキシマブの登場など多くの知見を踏まえ，2016 年に本邦初の PCNSL についてのガイドラインが発表さ れ, PCNSL に対する一次治療として HD-MTX を基盤と した多剤併用療法が寬解導入療法として推奨された。そ の中でもリッキシマブ (rituximab), HD-MTX, プロカ ルバジン (procarbazine), ビンクリスチン (vincristine) による R-MPV 療法と, それに引き続いた地固めの減量 全脳放射線治療 (reduced-dose whole brain radiation therapy：隇量 WBRT〕と大量シタラビン療法〔high dose cytarabine (AraC) : HD-AraC〕による一連の治療は良好 な治療成績として報告された ${ }^{25)}$. また，ブルトン型チロ シンキナーゼ（Bruton's tyrosine kinase：BTK）阻害剤で あるチラブルチニブ（tirabrutinib）が 2020 年 3 月に承 認, 5 月に発売され, 本邦での治療成績は諸外国に先駆 けて向上する可能性もある. 本稿では PCNSL の現状を 脳神経外科の視点から解説する.

\section{中枢神経系原発リンパ腫の疫学と症状}

PCNSL は高歯者に多い疾患で 60 ～70 歳代に好発し， 全国脳腫腸統計（2005 2008 年）では 70 歳以上の原発 性脳腫瘍において髄膜腫, 神経膠腫, 下垂体腺腫に次い で 4 番目に多く, 10.6\%を占める ${ }^{5)}$. 本邦での脳腫瘍全体 に占める割合は，1984〜2000 年では 3.1\%だったのが, 2001 2004 年では 3.5\%，2005 2008 年では $4.9 \%$ と頭 蓋咽頭腫を抜いて第 5 位となったが，これは人口の高齢 化が影響していると考えられる。 今後, 本邦でも human immunodeficiency virus (HIV) 感染や臟器移植後の免疫 抑制状態で発生する PCNSLが海外のように増加してく る可能性もある ${ }^{15)}$.

PCNSL の初発症状は腫瘍が発生した部位の局所神経
脱落症状の頻度が最も高い (55\%)。 その他, 精神症状や 行動異常, 認知機能低下, 頭痛・吐き気・嘔吐などの頭 蓋内圧元進症状が $1 / 3$ 以上で出現するが，症状の進行が 週単位またはそれ以上と早いことも特徵である。初発症 状としての痤攣の頻度は $5 \%$ 程度である.

\section{中枢神経系原発リンパ腫の表面マーカーと 遺伝子変異の特徵}

PCNSLが他のリンパ腫と比較して予後が不良なのは, 血液脳関門が存在して脳への抗がん剂の到達が不良であ ることが原因の 1 つとして考元られる。 その他, DLBCL の組織型を示す PCNSL の特徵としては, CD10 陽性の頻 度が低いことと, 特に MUM1 (multiple myeloma oncogene) /IRF4（interferon regulatory factor 4）陽性の頻度が 84〜 93\% と末梢性リンパ節発生の DLBCL の $53 \%$ と比べ て高いことが挙げられる7)20)。この結果として, PCNSLDLBCL では GCB (germinal-center B-cell-like) type が $1 / 4$ 未満程度と有意に低くなり, ABC (activated B-celllike) type を含めた non-GCB type が多い. また, DLBCL ではさまざまな遺伝子異常が報告されているが，そのう ち MYD88 の L265P 変異とCD79B の Y196 変異は腫瘍発 生に関わる遺伝子変化として重視されている6 ${ }^{61)}$. これ らのいずれか，または両者の変異がある PCNSL は約 $3 / 4$ で，末梢リンパ節発生の DLBCLの $42 \%$ と比べると明ら かに変異が起こっている頻度が高く, その結果として BCR（B cell receptor：B 細胞受容体）シグナル伝達の活 性化が起こり, 下流の $\mathrm{NF}-\kappa \mathrm{B}$ 経路を含めた $\mathrm{B}$ 細胞系り ンパ球細胞の生存, 活性化, 増殖, 成熟および分化のシ グナルが恒常的に活性化されている. BTK は BCR シグ ナル伝達経路の下流に位置する重要な調節因子である. $\mathrm{B}$ 細胞性非ホジキンリンパ腫, 特に PCNSL では, BCR シグナル伝達経路が恒常的に活性化していることが知ら れており, BTK は分子標的として注目されている ${ }^{9)}$.

GCB type は, 以前は $\mathrm{ABC}$ type を含めた non-GCB type と比べて予後が良好と報告されていたが16), リッキシマ ブ登場後にその差はなくなったとされた ${ }^{30)}$. その後，第 1 世代の BTK 阻害剤であるイブルチニブ（ibrutinib）が 登場し，イブルチニブはむしろ GCB type のほうが効き にくく，予後が不良であることが報告された ${ }^{32}$.

\section{中枢神経系原発リンパ腫の画像の特徵}

PCNSL は前頭葉や基底核, 深部白質の発生が多く, 多 発の頻度は34〜75\%と報告によってばらつきがあ 

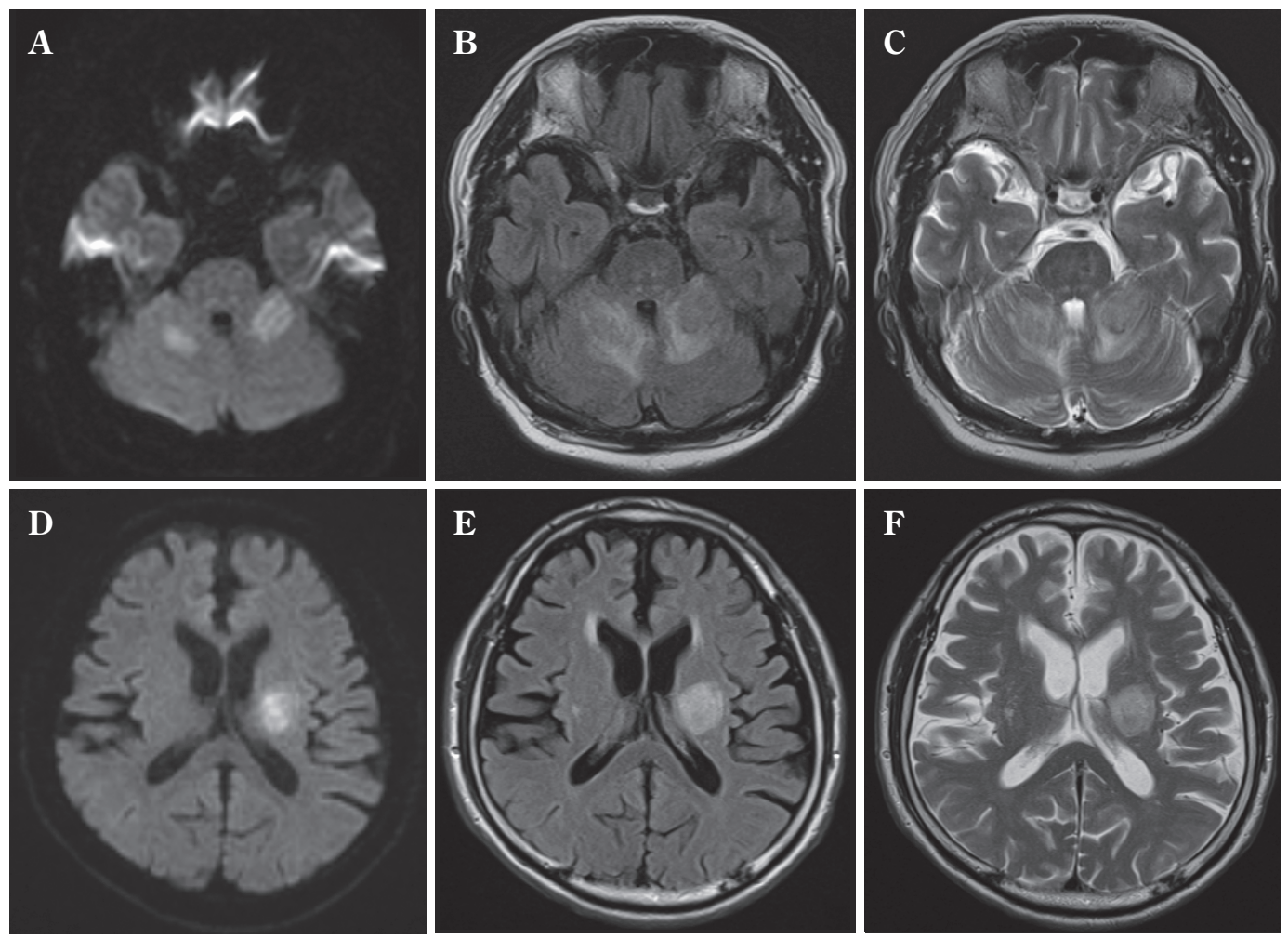

Fig. 1 Primary central nervous system lymphoma cases as stroke mimic A 77-year-old male suffered from subacute dizziness. Magnetic resonance imaging (MRI) revealed high intensity on diffusion-weighted imaging (DWI) at the bilateral cerebellar hemisphere (A). Note that high-intensity lesions on FLAIR (B) and T2-weighted images (C) are found around the DWI high-intensity signal. A $75^{-}$year-old male suffered from subacute dysarthria and right hemiparesis. MRI revealed a high-intensity area on DWI from the left internal capsule to corona radiata (D). Note that high-intensity lesions on FLAIR (B, E) and T2-weighted images $(\mathbf{C}, \mathbf{F})$ are larger than DWI high-intensity lesions $(\mathbf{A}, \mathbf{D})$.

る)28). HIV などの免疫抑制状態で発症するもの以外の, 免疫力が正常な場合は均一に造影されることが多いのも 特徵である。単純 CT では淡い高吸収病変として描出さ れるが，これは高い細胞密度を反映しているとされる。 同様の理由で単純 MRI の拡散強調画像では高信号を呈 し, 拡散強調画像から計測される「みかけの拡散係数」 の值は膠芽腫を含めたびまん性グリオーマや転移性脳腫 瘍よりも低い ${ }^{34)}$ 。 ただし， みかけの拡散係数值の分布は 膠芽腫や転移性脳腫瘍とも一部 overlap している。腫瘍 周辺の非造影部に, 腫瘍浸潤を示す拡散強調画像での強 い高信号が存在する場合などでは膠芽腫を示唆する所見 として PCNSL との鑑別に有用である ${ }^{19)}$. また, PCNSL は拡散強調画像が高信号を呈するため, 脳梗塞とまちが われるリスクがある。 Fig. 1 に, 初発時に脳梗塞と診断 された PCNSL の患者の画像を示す. PCNSL はT2 強調 画像では低信号を呈することが多く, 拡散強調画像高信 号部よりも T2/FLAIR 高信号部の範囲が広いことなど,
注意深く読影すれば単純 MRIでも脳梗塞と鑑別できる 可能性が高いが, 小さな病変での判別は難しいため, 発 症形式などの病歷から判断することも重要である.

PCNSLが免疫応答の正常な患者に発生した場合では, ガドリニウム造影剤で均一に造影され，周辺に強い脳浮 腫を伴うことが多い. 腫瘍内の粗大出血は $2 \sim 8 \%$ とまれ だが，T2*で微小出血を伴うことはまれではない18)299. Proton MR spectroscopy では，造影される腫瘍内では $\mathrm{n}$ acetyl-aspartate（NAA）が消失し, choline の高いピーク を認める．特に，均一に造影され中心性壊死を伴わない にもかかわらず，高い lipids のピークが出現することは PCNSL の特徵であり, 䯣内腫瘍で造影 $\mathrm{T} 1$ 強調画像にお いて内部に明らかな壊死がない画像で, lipidsの高い ピークが存在しない場合は, DLBCLの可能性は乏し $\omega^{35)}$. 


\section{中枢神経系原発リンパ腫の診断と 画像効果判定}

PCNSL の診断で最も重要なのは，手術による組織診 断であることは疑いがない。一方で PCNSL は脳の深部 の eloquent area に発生し, 組織診断による症状出現, 悪 化のリスクが無視できない場合がある。そのような場 合, 髄液の細胞診による診断が試みられるが, PCNSL に おける髄液細胞診の陽性率は低い。一方, flow cytometry は細胞診で Class IIIの場合には陽性となる率が高く, 髄 液細胞診が陰性でも $10 \%$ 程度の確率で陽性となる ${ }^{7)}$ 。こ のため, 腫瘍が生検可能になるまで増大して神経症状が 悪化するまでに，積極的に取り入れるべき検査法である といえる。 また, 䯣液細胞診の結果の特異度は高いため, CD20 陽性かどうかを診断するのにも有用であるし，特 に免疫染色よりも結果が早く得られるため, 治療開始を 急ぐ病状のときには有用性が高い31).

PCNSL と診断された場合に行うべき検査について, National Comprehensive Cancer Network（NCCN）ガイド ラインでは, lactate dehydrogenase, HIV の検査, 眼内リ ンパ腫の検索, 安全に施行可能なら髄液検査, 髄液検査 が陽性なら春髄の MRI 検査を挙げている。ただし, 日本 では比較的 MRI 検査が容易なため，脊髄の MRI 検査は 治療開始前に行っておくことが望ましい. 全身の FDGPET または体部（頝部〜骨盤）のCT が挙げられている が，ガイドラインに FDG-PET が登場したことで，この 検査の有用性が広く認識されてきたと考えられる。その 他, category 2B（比較的低レベルのエビデンスに基づい ており，その介入が適切であるという $\mathrm{NCCN}$ のコンセン サスが存在する)で骨髄検査と 60 歳を超えた男性の精巣 超音波検査が推奨されているが，今後本邦でも積極的に 取り入れられていくと予想される.

International Primary CNS Lymphoma Collaborative Group（IPCG）は, PCNSL の画像撮像プロトコールにお ける推奨を発表している ${ }^{4)} .3$ テスラ装置での最小限行 うべき撮像を要約すると, 造影前の thin sliceの $\mathrm{T} 1$ 強調 画像 (または volume 撮像), 拡散強調画像と $\mathrm{T} 2$ 強調画 像, dynamic susceptibility contrast による灌流画像, 造影 後の T2-FLAIR 画像, thin slice の T1 強調画像（または volume 撮像) を含んだ撮像を行うように推奨している. T2-FLAIR は T1 強調画像の要素も含み, 造影後のコント ラストに優れることで, 微小な腫瘍性病変の検出力が高 まることがポイントである.

IPCG は, PCNSL の治療効果判定における, 腫瘍量の 測定の課題についても言及している ${ }^{4)}$. 具体的には,
PCNSL は造影病変の測定が簡単な症例のみならず，測 定できないような形状のもの, 造影されずに FLAIR や拡 散強調画像高信号で拡がる, いわゆる大脳リンパ腫症 (lymphomatosis cerebri) や, 大脳リンパ腫症との移行型 のような症例が存在する（Fig. 2)。現状では，測定でき ない症例の多くは臨床試験から除外される対象となる。 また，PCNSL は治療後にわずかに造影が残ることがあ り，術後洀痕としての造影所見残存も含め，その判定に 悩むことがある.IPCGではそれについて unconfirmed complete response（CRu）と定義した（Fig.3）。そのほ かにステロイドの継続使用，網膜色素上皮細胞の微小な 異常所見が $\mathrm{CRu}$ に該当する ${ }^{1)}$ ．また腫瘍が大きい場合に は瘢痕部分が $\mathrm{T} 1$ 強調画像で高信号を呈す可能性があり, 単純と造影の対比が必要である (Fig. 3)。T1 強調画像で の高信号所見が残存する場合の臨床的意義は現時点で不 明である。

\section{初発の中枢神経系原発リンパ腫の治療}

PCNSL の治療は, 当初は全脳放射線照射 (whole brain radiotherapy：WBRT）であったが，全生存期間（overall survival：OS）が $1 \sim 1.5$ 年と短く, 放射線単独療法のみ での治療開発の限界やWBRT 後に発生する強い神経毒 性の問題もあり，寛解導入目的の化学療法を先行させる 治療が開発されることになった ${ }^{23)}$.その後, HD-MTXを 寬解導入療法として行い, それに引き続いてWBRTを行 うことが本邦の標準治療であったが，HD-MTX 単独で の寬解率が高くないことや, $30 \mathrm{~Gy} / 15$ fraction の WBRT, 腫瘍が残存した場合にその部に追加照射 10〜20 Gy を 行った後, 比較的早期に放射線治療による脳障害として の白質脳症, vasculopathy としての脳梗塞や海綿状血管 腫の発生，白質壊死（cystic malacia）などが出現するた め, さらなる化学療法の強化と放射線線量の減量が求め られている。本邦では JCOG1114 臨床試験で HD-MTX と WBRTへのテモゾロミドの上乗せ効果が検討された が，残念ながら再発までの期間 (progression free survival：PFS）が短縮した結果であった ${ }^{24)}$. Negative study となった原因については現在解析中で, 結果の報告が待 たれる。

HD-MTX を基盤とした多剤併用療法の中では, 特に R-MPV 療法の寬解導入率が高く, 大量 MTX と比較して も grade 3 以上の非血液毒性の有害事象の頻度はそれほ ど上昇しない ${ }^{1325)}$. 副作用管理が容易な治療強度で, 治 療効果とのバランスがよいことから本邦においても寬解 導入療法の標準治療として認知度が高まっている， R- 

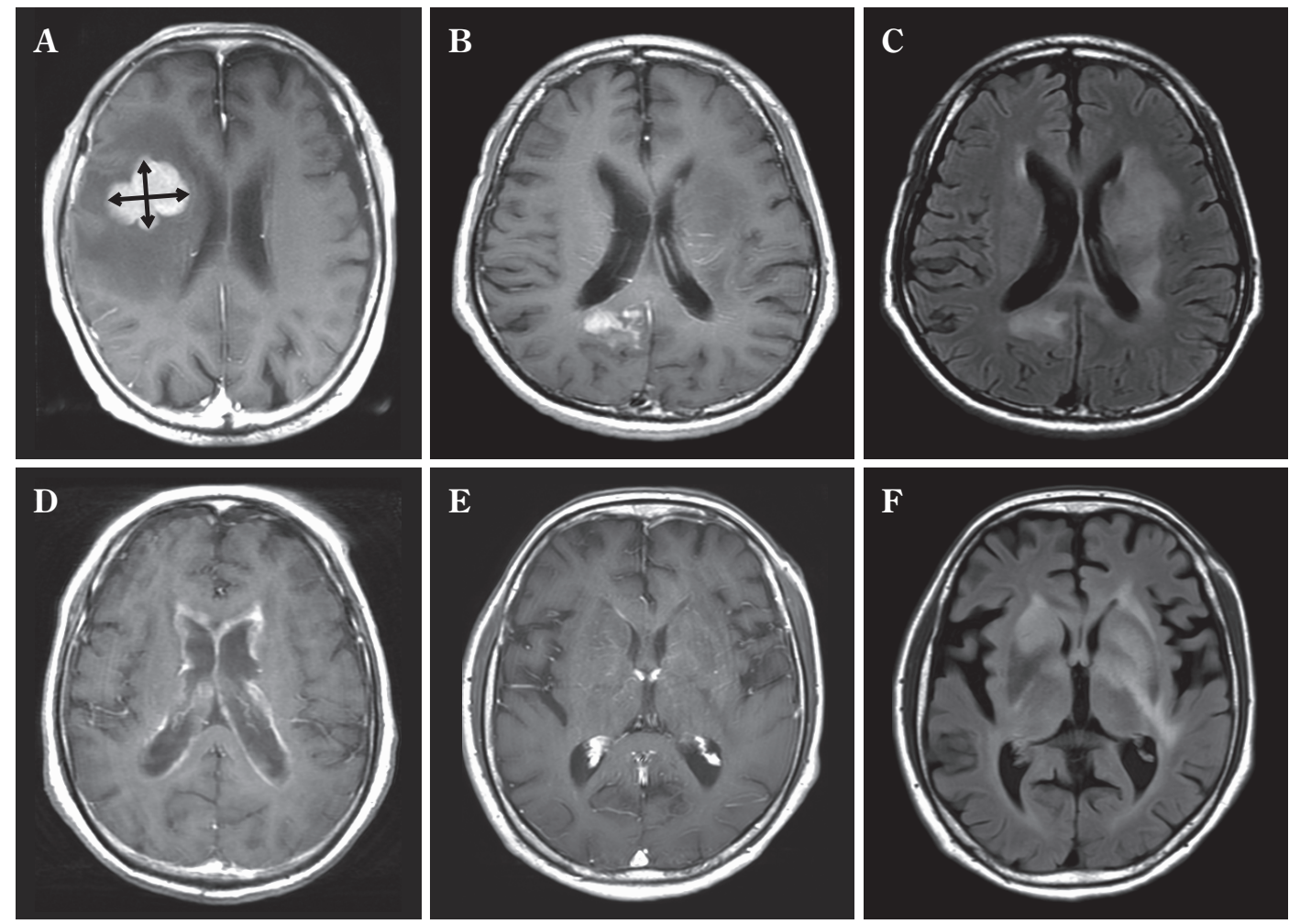

Fig. 2 Primary central nervous system lymphoma in a 79-year-old male (A), a 59-year-old male (B, C) , an 82-year-old male (D), and a 69-year-old male (E, F). Post-contrast enhanced T1-weighted images (A, B, D, E) and FLAIR images $(\mathbf{C}, \mathbf{F})$. Challenges of bidirectional measurements of primary central nervous system lymphoma (PCNSL) tumor burden. A single-lobulated PCNSL mass allows straightforward bidirectional measurement (A, double arrows). However, bidirectional measurements become more challenging with varied imaging patterns, such as with heterogeneous enhancement and some linear perivascular enhancement (B, D), ependymal enhancement (D), and linear perivascular enhancement with features of lymphomatosis cerebri $(\mathbf{E})$.

MPV 療法, HD-AraC を含め, 脳神経外科医が施行可能 な薬物療法の概説は別稿に記載したので参照された い36. PCNSLに対してR-MPV 療法を5 コース行い, 完 全寬解が得られない場合はさらに 7 コースまで継続す る. 完全寬解が得られた患者には地固めのWBRTは減量 WBRT として $23.4 \mathrm{~Gy} / 13$ fraction で行い, さらに $\mathrm{HD}^{-}$ $\mathrm{AraC}$ を 2 コース行う。この群での治療成績は PFS 中央 值が 7.7 年, 3 年後の患者生存率が $87 \%$ であった ${ }^{25)}$. 一 方, R-MPV 療法 7 コースで完全寬解が得られなかった 患者には $45 \mathrm{~Gy} / 25$ fraction の WBRT が施行されたが, 45 $\mathrm{Gy}$ の放射線照射後の認知機能低下の問題が改めて強調 された ${ }^{17)}$ 。試験全体での PFS 中央值は 3.3 年, OS 中央 值は 6.6 年, 5 年生存率は $70 \%$ と報告された ${ }^{25)}$.

高歯者の PCNSL は, 前述の治療成績が改善している 米国, 改善していないスウェーデン, いずれにも共通し て治療成績が不良であった ${ }^{10222}$. 治療成績が優れている R-MPV 療法を中心とした治療を行ったとしても, やは
り高齢者では若年者と比べて明らかに治療成績が不良と された ${ }^{25)}$. 高齢者では, 臟器機能の低下による化学療法 に対する耐性の低下の問題, 放射線治療による脳障害が 出やすい問題など課題が多い. 高齢者においては $\mathrm{R}^{-}$ MPV 療法により完全寬解が得られた後の $23.4 \mathrm{~Gy}$ の減量 WBRT についても, 行うべきかどうかのコンセンサスが 得られておらず, 薬物療法の開発と放射線治療の減量や 回避が喫緊の課題である ${ }^{17)}$.

一方，年齢が若い PCNSL の場合は，さらなる治療成 績向上のために初発時に自家幹細胞移植（autologous stem cell transplantation: ASCT)/自家未梢血幹細胞移植 (autologous peripheral blood stem cell transplantation: auto-PBSCT) を併用した大量化学療法（high dose chemotherapy：HD-CTx）を地固めとして行うことも検討さ れる ${ }^{14)}$. PCNSL に対する HD-CTx-ASCT の第III相臨床 試験のデータはなく, 第 II 相のデータのみであること と, 治療完遂率などが課題で3), 本邦のガイドラインで 

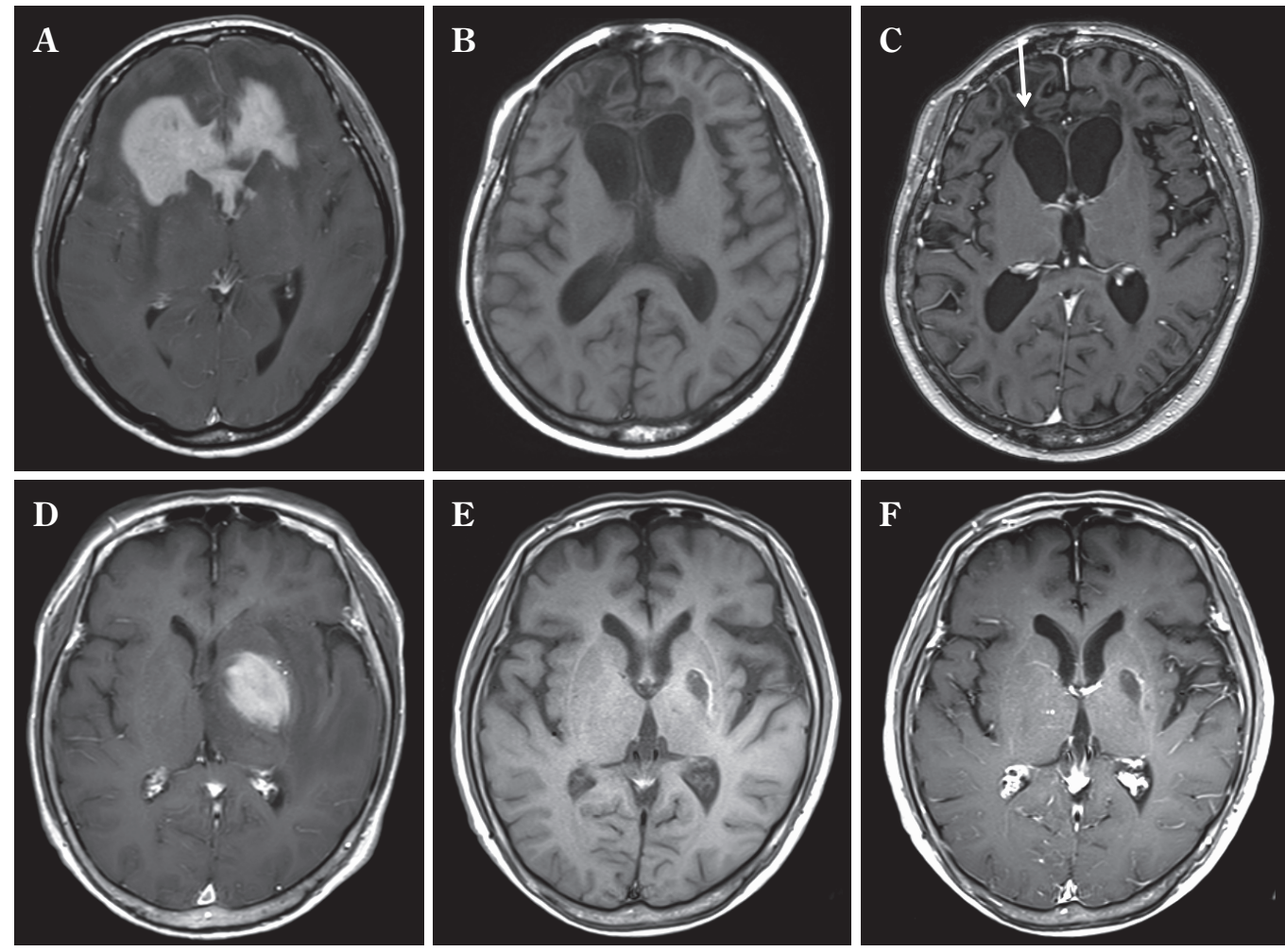

Fig. 3 Representative cases of unconfirmed complete response $\left(\mathbf{A}^{-} \mathbf{C}\right)$ and complete response (D-F). Post-contrast enhanced T1-weighted images (T1WI) (A, C, D, F) and precontrast T1WI (B, E). A 43-year-old female with primary central nervous system lymphoma (PCNSL) at the bifrontal lobe (A) was treated with rituximab, high-dose methotrexate, procarbazine, and vincristine, followed by whole-brain radiotherapy and high-dose cytarabine ( $\mathrm{R}-\mathrm{MPV}-\mathrm{R}-\mathrm{A})$. A small but persistent enhancing abnormality is observed at the right frontal lobe (C, arrow). A 71-year-old female with PCNSL at the left basal ganglia (D) was treated with R-MPV-A. A small linear high intensity was observed both on pre-contrast (E) and post-contrast (F) T1WI.

は現時点では推奨されていない. PCNSLの HD-CTxASCT においてキードラッグの1つといえるチオテパ (thiotepa)が悪性リンパ腫に対して 2020 年 3 月に適応が 追加承認され, 今後は HD-CTx-ASCT の治療開発が進む ことが期待される。

\section{再発の中枢神経系原発リンパ腫の治療}

再発の PCNSL に対する本邦のガイドラインは, 初発 時に HD-MTX を含む治療により長期間の奏効が得られ た場合に, HD-MTXを含む治療の $\mathrm{re}^{-}$challenge を推奨し ている. 一方, NCCNのガイドラインはもう少し踏み込 んで記載されている (Fig. 4), 図で特に記載していない 場合は category 2A (比較的低レベルのエビデンスに基づ いており，その介入が適切であるという NCCNの「統一 した」コンセンサスが存在する）に相当する。まず，臨
床試験が存在する場合はそれに登録することを推奨して いる，続いて，前治療でWBRTを施行している場合は， 化学療法と, それに追加または単独の髄注化学療法, 局 所放射線治療が挙げられており，ここの HD-MTXを基 盤とした化学療法は記載されていない。 また, 寛解導入 療法により完全寛解が得られた場合に HD-CTx-ASCT を行うことが category $2 \mathrm{~B}$ とて記載されているが, WBRT 後では神経毒性に考慮すべき，と追記されてい る。実臨床では WBRT 後でも, 再発した PCNSL に対し て HD-MTX を基盤とした化学療法や HD-CTx-ASCTを 選択せざるを得ない状況はあるが，寛解が得られても神 経毒性の発生により状態が悪化することもある.

NCCNのガイドラインにおいて, HD-MTX や HD$\mathrm{CTx}-\mathrm{ASCT}$ 後の再発までの期間を 12 力月で区切り, 12 力月未満の再発では前治療の効果がそしいと判断してい る点は参考になる。すなわち, HD-MTXを基盤とした化 


\begin{tabular}{|c|c|c|}
\hline $\begin{array}{l}\text { Any type of } \\
\text { treatment history }\end{array}$ & & - Consider clinical trial \\
\hline \multirow[t]{2}{*}{ Prior WBRT } & & $\begin{array}{l}\text { CTx (systemic and/or intra-CSF) } \\
\text { - High-dose CTx with stem cell rescue (2B) } \\
\text { (risk of neurotoxity should be considered) } \\
\text { - Focal irradiation } \\
\text { - Palliative/best supportive care } \\
\end{array}$ \\
\hline & \begin{tabular}{|l|}
$\begin{array}{l}\text { Previous response } \\
\text { with long duration } \\
\geq 12 \text { months }\end{array}$ \\
\end{tabular} & $\begin{array}{l}\cdot \text { Re-HD-MTX } \pm \text { other CTx } \\
\text { - Other systemic CTx } \\
\text { - High-dose therapy with stem cell rescue }(2 \mathrm{~B}) \\
\text { - Palliative/best supportive care }\end{array}$ \\
\hline \multirow{2}{*}{$\begin{array}{l}\text { Prior HD-MTX } \\
\text { based regimen } \\
\text { without prior RT }\end{array}$} & \begin{tabular}{|l|}
$\begin{array}{l}\text { No response or } \\
\text { short duration } \\
<12 \text { months }\end{array}$ \\
\end{tabular} & $\begin{array}{l}\text { - Other systemic CTx } \\
\text { - WBRT or involved field RT } \pm \text { other CTx } \\
\text { - High-dose CTx with stem cell rescue (2B) } \\
\text { - Palliative/best supportive care } \\
\end{array}$ \\
\hline & \begin{tabular}{|l|} 
Previous response \\
with long duration \\
$\geq 12$ months \\
\end{tabular} & $\begin{array}{l}\text { - Second HD-CTx with stem cell rescue } \\
\text { - Other systemic chemotherapy } \\
\text { - Best supportive care }\end{array}$ \\
\hline $\begin{array}{l}\text { Prior HD-CTx } \\
\text { with stem cell } \\
\text { rescue }\end{array}$ & \begin{tabular}{|l|} 
No response or \\
short duration \\
$<12$ months \\
\end{tabular} & $\begin{array}{l}\text { - Other systemic CTx } \\
\text { - WBRT or involved field RT } \pm \text { other CTx } \\
\text { - Other systemic CTx } \\
\text { - Palliative/best supportive care }\end{array}$ \\
\hline
\end{tabular}

CTx : chemotherapy, 2B : category 2B (https://www.nccn.org/professionals/physician_gls/pdf/cns.pdf)

Fig. 4 National Comprehensive Cancer Network（NCCN） guideline 2021 for relapsed or refractory primary central nervous system lymphoma

All recommendations are category $2 \mathrm{~A}$ unless otherwise indicated. Category $2 \mathrm{~A}$ : based upon low-level evidence, there is uniform NCCN consensus that the intervention is appropriate. Category 2B : based upon low-level evidence, there is NCCN consensus that the intervention is appropriate.

学療法後 12 力月未満で再発した場合は, HD-MTX を基 盤とした化学療法を再度行うことを推奨していない. PCNSL は化学療法に反応することが多いため, HDCTx-ASCT を行えない場合は HD-AraC 療法を含む ESHAP 療法（エトポシド,メチルプレドニゾロン, シタ ラビン, シスプラチン）やDHAP 療法（デキサメタゾ ン, シタラビン, シスプラチン)などの多剤併用療法や, 白金製剤を含む ICE 療法 (イホスファミド, シスプラチ ン, エトポシド) や CARE (カルボプラチン, エトポシ ド）療法などの多剂併用療法，そしてこれらにリッキシ マブを追加することや, R-IE 療法（リツキシマブ, イホ スファミド，エトポシド）を含めたさまざまなレジメン が検討されるが，エビデンスレベルの高いものは存在し ない.

一方，本邦では再発・難治の PCNSL に対して，BTK 阻害剤のチラブルチニブという新たな治療手段を得てい る。最初に登場したイブルチニブは第 1 世代の BTK 阻 害剂に分類されるが off-targets 作用が多く, BTK 阻害以 外にも interleukin 2-inducible T cell kinase (ITK), EGFR, TEC, bone marrow tyrosine kinase gene in chromosome X（BMX）などに作用する ${ }^{24)}$ 。また，イブルチ
ニブ投与患者の $4.6 \%$ に心房細動が発生しており, 明確 な原因は不明だが off-targets 作用の可能性が高い.さら に，イブルチニブの再発 PCNSL に対する耐性獲得機序 として, BTK の kinase domain の 481 番目の cysteine が serine に置換される C481S 遺伝子変異が報告された 33 .

第 2 世代の BTK 阻害剤に分類されるチラブルチニブ は本邦での第 I / II 相臨床試験を経て ${ }^{26)}, 2020$ 年 5 月に 再発・難治の PCNSL に対する新しい治療として発売さ れた。チラブルチニブは BTK の SRC 相同ドメイン 3 内 の Y 223 における自己リン酸化を不可逆的に強力に阻害 する共有結合型の経口剤で $\mathrm{C} 481 \mathrm{~S}$ 遺伝子変異にも有効で あり, off-targets 作用が少なく心房細動の発生頻度は上 昇しない2 ${ }^{26) 27)}$ ，チラブルチニブには白質脳症のリスクな どは報告されておらず，高齢者では特に有用な治療手段 といえる。臨床試験における再発までの期間の中央值は 食後の $480 \mathrm{mg}$ 投与が 11.1 力月, 空腹時の $480 \mathrm{mg}$ 投与が 5.8 カ月だが, 食後では area under the blood concentration time curve（AUC）が上昇して副作用のリスクが高くな るため，空腹時に投与する設定となった。投与期間中は 化学療法が休薬できることや，放射線照射開始時期を遅 らせるメリットなども挙げられる。代表症例を提示する 

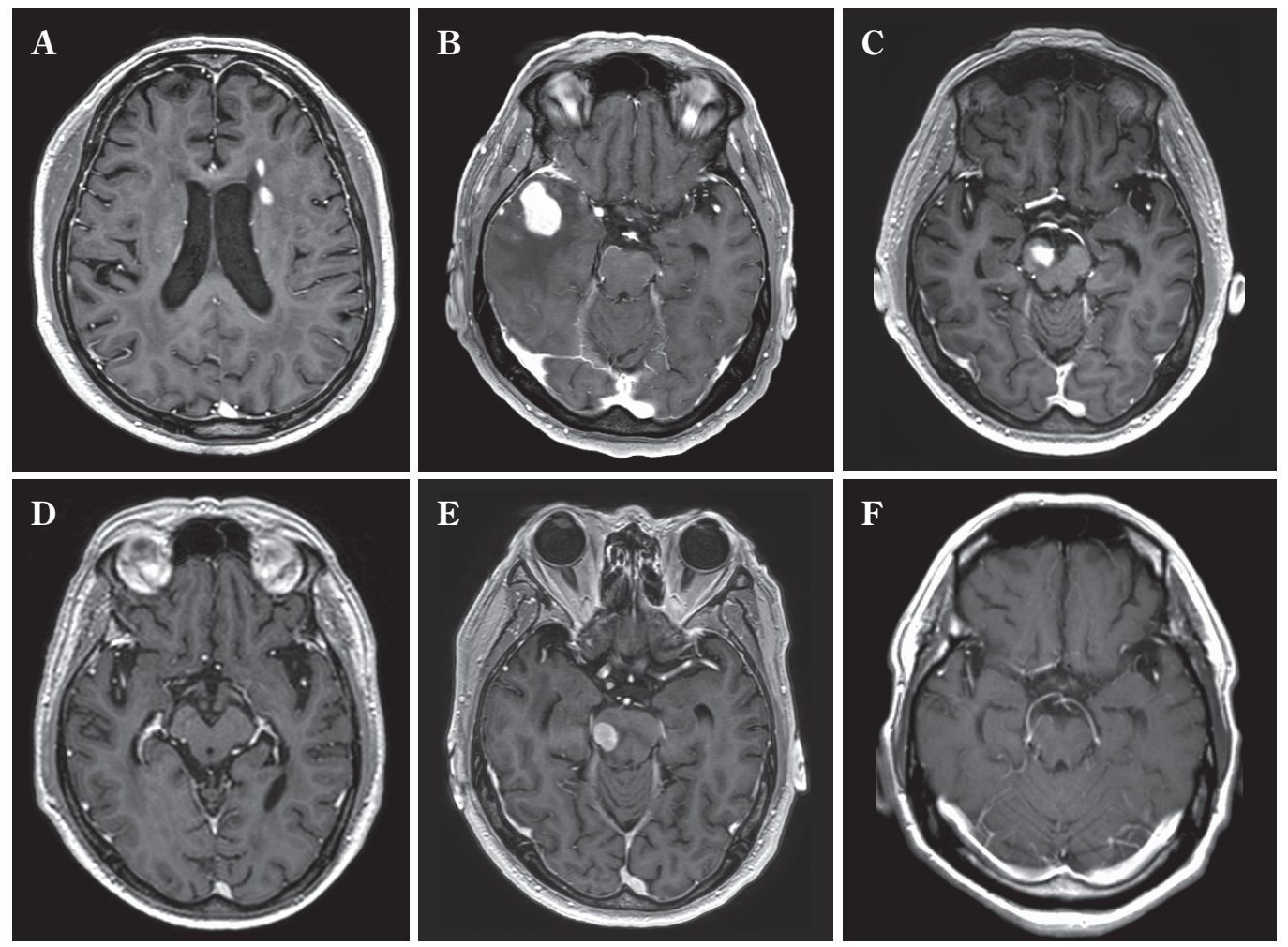

Fig. 5 A representative case of treatment for primary central nervous system lymphoma in a 63-year-old male

Recurrence after nine courses of high-dose methotrexate (HD-MTX) and whole-brain radiotherapy when he was aged 65 (A). He was administered $320 \mathrm{mg}$ of tirabrutinib and complete response (CR) was achieved. After 22 months, progressive disease (PD) was observed at the right temporal lobe, and he was treated with high-dose cytarabine (HD-AraC) (B). After four cycles of $\mathrm{HD}^{-} \mathrm{AraC}, \mathrm{PD}$ was observed at the midbrain $(\mathbf{C})$. Subsequently, the patient was administered rituximab, HD-MTX, procarbazine, and vincristine (R-MPV) and CR was achieved (D). Ten weeks after finishing seven cycles of R-MPV, PD was observed at the midbrain (E). He was administered $480 \mathrm{mg}$ of tirabrutinib rechallenge and CR was achieved when he was aged 69 ( F).

(Fig. 5).今後のデー夕蓄積により，長期間効果が持続す る患者の分子遺伝学的特徵の分析や耐性獲得機序の解明 を含め, さらなる BTK 阻害剤の開発が期待される。千 ラブルチニブについては特に, BCR シグナル伝達経路の 異常が少ないと予想される治療早期のラインでの開発が 期待されている。

\section{中枢神経系原発リンパ腫の予後因子}

PCNSL の予後因子は, 前述の年齢以外には Eastern Cooperative Oncology Group (ECOG) の performance status（PS）などの全身状態の指標が重要であることが 知られている ${ }^{15)}$. International Extranodal Lymphoma Study Group（IELSG）は, PCNSL の予後不良因子とし て, 年齢が 60 歳より上, PS が 2 以上, 血清 lactate dehy- drogenase（ $\mathrm{LDH})$ 上昇, 髄液中のタンパク上昇, 脳深部 病巣あり,の 5 つの項目を報告した ${ }^{12)} .2$ 年生存率は, これらが $0 \sim 1$ 個の場合 $80 \%, 2 \sim 3$ 個の場合 $48 \%, 4$ ～ 5 個の場合 $15 \%$ で統計学的に有意差を示した。また, Memorial Sloan Kettering Cancer Center (MSKCC) では 予後不良因子として 50 歳より上の年齢と, Karnofsky performance status（KPS） 70 未満を挙げ，OS 中央值は 50 歳以下で 8.5 年, 50 歳以上かつ KPS 70 以上で 3.2 年, 50 歳以上で KPS 70 未満は 1.1 年と報告した ${ }^{2)}$.これらの 予後因子は治療開発のための臨床試験や日常診療に重要 な情報となる。

\section{おわりに}

中枢神経系原発リンパ腫アップデートとして, PCNSL 
の分子遺伝学的情報, 画像情報, 初発, 再発の治療につ いて概説した。本全体での治療成績の向上には大量メ トトレキサート療法に代わり，新しい標準治療として認 識されてきている $\mathrm{R}-\mathrm{MPV}$ 療法の普及や若年患者での末 梢血幹細胞移植を伴う大量化学療法の導入, そして再発 時にチラブルチニブを含めた適切な治療選択を行うこと が肝要である. 本邦での治療成績が以前よりも向上し, 世界に先駆けた良好な治療成績の達成とさらなる治療開 発につながることを祈念して本稿を結ぶ.

\section{COI}

著者は日本脳神経外科学会への COI 自己申告の登録を完了 しています。本論文に関して開示すべき COI はありません。

\section{文 献}

1) Abrey LE, Batchelor TT, Ferreri AJ, Gospodarowicz M, Pulczynski EJ, Zucca E, Smith JR, Korfel A, Soussain C, DeAngelis LM, Neuwelt EA, O'Neill BP, Thiel E, Shenkier T, Graus F, van den Bent M, Seymour JF, Poortmans P, Armitage JO, Cavalli F ; International Primary CNS Lymphoma Collaborative Group: Report of an international workshop to standardize baseline evaluation and response criteria for primary CNS lymphoma. J Clin Oncol 23: 5034-5043, 2005.

2) Abrey LE, Ben-Porat L, Panageas KS, Yahalom J, Berkey B, Curran W, Schultz C, Leibel S, Nelson D, Mehta M, DeAngelis LM: Primary central nervous system lymphoma : the Memorial Sloan-Kettering Cancer Center prognostic model.J Clin Oncol 24:5711-5715, 2006.

3) Alnahhas I, Jawish M, Alsawas M, Zukas A, Prokop L, Murad $\mathrm{MH}$, Malkin M : Autologous stem-cell transplantation for primary central nervous system lymphoma: systematic review and meta-analysis. Clin Lymphoma Myeloma Leuk 19: e129-e141, 2019.

4) Barajas RF, Politi LS, Anzalone N, Schoder H, Fox CP, Boxerman JL, Kaufmann TJ, Quarles CC, Ellingson BM, Auer D, Andronesi OC, Ferreri AJM, Mrugala MM, Grommes C, Neuwelt EA, Ambady P, Rubenstein JL, Illerhaus G, Nagane M, Batchelor TT, Hu LS : Consensus recommendations for MRI and PET imaging of primary central nervous system lymphoma : guideline statement from the International Primary CNS Lymphoma Collaborative Group (IPCG). Neuro Oncol 23: 1056-1071, 2021.

5) Brain Tumor Registry of Japan (2005-2008). Neurol Med Chir (Tokyo) 57 (Supple 1) : 9-102, 2017.

6) Bruno A, Boisselier B, Labreche K, Marie Y, Polivka M, Jouvet A, Adam C, Figarella-Branger D, Miquel C, Eimer S, Houillier C, Soussain C, Mokhtari K, Daveau R, HoangXuan $\mathrm{K}$ : Mutational analysis of primary central nervous system lymphoma. Oncotarget $\mathbf{5}: 5065-5075,2014$.

7) Camilleri-Broet $\mathrm{S}$, Criniere E, Broet P, Delwail V, Mokhtari K, Moreau A, Kujas M, Raphael M, Iraqi W, Sautes-Fridman C, Colombat P, Hoang-Xuan K, Martin A : A uniform activated $\mathrm{B}$-cell-like immunophenotype might explain the poor prognosis of primary central nervous system lymphomas: analysis of 83 cases. Blood $107:$ 190-196, 2006.
8) Canovi S, Campioli D : Accuracy of flow cytometry and cytomorphology for the diagnosis of meningeal involvement in lymphoid neoplasms : A systematic review. Diagn Cytopathol 44: 841-856, 2016.

9) Chapuy B, Roemer MG, Stewart C, Tan Y, Abo RP, Zhang L, Dunford AJ, Meredith DM, Thorner AR, Jordanova ES, Liu G, Feuerhake F, Ducar MD, Illerhaus G, Gusenleitner D, Linden EA, Sun HH, Homer H, Aono M, Pinkus GS, Ligon AH, Ligon KL, Ferry JA, Freeman GJ, van Hummelen P, Golub TR, Getz G, Rodig SJ, de Jong D, Monti S, Shipp MA : Targetable genetic features of primary testicular and primary central nervous system lymphomas. Blood 127 : 869-881, 2016.

10) Eloranta S, Branvall E, Celsing F, Papworth K, Ljungqvist M, Enblad G, Ekstrom-Smedby K : Increasing incidence of primary central nervous system lymphoma but no improvement in survival in Sweden 2000-2013. Eur J Haematol $100: 61-68,2018$.

11) Farrall AL, Smith JR: Changing incidence and survival of primary central nervous system lymphoma in Australia : a 33-year national population-based study. Cancers (Basel) 13: 403, 2021.

12) Ferreri AJ, Blay JY, Reni M, Pasini F, Spina M, Ambrosetti A, Calderoni A, Rossi A, Vavassori V, Conconi A, Devizzi L, Berger F, Ponzoni M, Borisch B, Tinguely M, Cerati M, Milani M, Orvieto E, Sanchez J, Chevreau C, Dell'Oro S, Zucca E, Cavalli F : Prognostic scoring system for primary CNS lymphomas : the International Extranodal Lymphoma Study Group experience. J Clin Oncol 21 : 266-272, 2003.

13) Ferreri AJ, Reni M, Foppoli M, Martelli M, Pangalis GA, Frezzato M, Cabras MG, Fabbri A, Corazzelli G, Ilariucci F, Rossi G, Soffietti R, Stelitano C, Vallisa D, Zaja F, Zoppegno L, Aondio GM, Avvisati G, Balzarotti M, Brandes AA, Fajardo J, Gomez H, Guarini A, Pinotti G, Rigacci L, Uhlmann C, Picozzi P, Vezzulli P, Ponzoni M, Zucca E, Caligaris-Cappio F, Cavalli F ; International Extranodal Lymphoma Study Group (IELSG) : High-dose cytarabine plus high-dose methotrexate versus high-dose methotrexate alone in patients with primary CNS lymphoma : a randomised phase 2 trial. Lancet 374: 1512-1520, 2009.

14) Gritsch D, Mrugala MM, Marks LA, Mangipudi K, Neal M, Wingerchuk DM, O'Carroll CB : Is autologous stem cell transplantation a safe and effective alternative to whole brain radiation as consolidation therapy in patients with primary central nervous system lymphoma? : a critically appraised topic. Neurologist $26: 137-142,2021$.

15) Grommes C, DeAngelis LM : Primary CNS lymphoma. $J$ Clin Oncol $35: 2410-2418,2017$.

16) Hans CP, Weisenburger DD, Greiner TC, Gascoyne RD, Delabie J, Ott G, Muller-Hermelink HK, Campo E, Braziel RM, Jaffe ES, Pan Z, Farinha P, Smith LM, Falini B, Banham AH, Rosenwald A, Staudt LM, Connors JM, Armitage JO, Chan WC : Confirmation of the molecular classification of diffuse large B-cell lymphoma by immunohistochemistry using a tissue microarray. Blood $103: 275-282,2004$.

17) Herrlinger U, Schafer N, Fimmers R, Griesinger F, Rauch M, Kirchen H, Roth P, Glas M, Bamberg M, Martus P, Thiel E, Korfel A, Weller M : Early whole brain radiotherapy in primary CNS lymphoma : negative impact on quality of life in the randomized G-PCNSL-SG1 trial. J Cancer Res Clin Oncol 143: 1815-1821, 2017.

18) Kickingereder P, Wiestler B, Sahm F, Heiland S, Roethke M, 
Schlemmer HP, Wick W, Bendszus M, Radbruch A : Primary central nervous system lymphoma and atypical glioblastoma : multiparametric differentiation by using diffusion-, perfusion-, and susceptibility-weighted MR imaging. Radiology 272: 843-850, 2014.

19) Kolakshyapati M, Adhikari RB, Karlowee V, Takayasu T, Nosaka R, Amatya VJ, Takeshima Y, Akiyama Y, Sugiyama K, Kurisu K, Yamasaki F : Nonenhancing peritumoral hyperintense lesion on diffusion-weighted imaging in glioblastoma : a novel diagnostic and specific prognostic indicator. $J$ Neurosurg 128:667-678, 2018.

20) Lin CH, Kuo KT, Chuang SS, Kuo SH, Chang JH, Chang KC, Hsu HC, Tien HF, Cheng AL : Comparison of the expression and prognostic significance of differentiation markers between diffuse large $\mathrm{B}$-cell lymphoma of central nervous system origin and peripheral nodal origin. Clin Cancer Res 12: 1152-1156, 2006.

21) Lionakis MS, Dunleavy K, Roschewski M, Widemann BC, Butman JA, Schmitz R, Yang Y, Cole DE, Melani C, Higham CS, Desai JV, Ceribelli M, Chen L, Thomas CJ, Little RF, Gea-Banacloche J, Bhaumik S, Stetler-Stevenson M, Pittaluga S, Jaffe ES, Heiss J, Lucas N, Steinberg SM, Staudt LM, Wilson WH : Inhibition of B cell receptor signaling by ibrutinib in primary CNS lymphoma. Cancer Cell $\mathbf{3 1}: 833-843$ e5, 2017.

22) Mendez JS, Ostrom QT, Gittleman H, Kruchko C, DeAngelis LM, Barnholtz-Sloan JS, Grommes C : The elderly left behind-changes in survival trends of primary central nervous system lymphoma over the past 4 decades. Neuro Oncol 20 : 687-694, 2018.

23) Milgrom SA, Yahalom $J$ : The role of radiation therapy in the management of primary central nervous system lymphoma. Leuk Lymphoma $\quad \mathbf{5 6}$ : 1197-1204, 2015.

24) Mishima K, Nishikawa R, Narita Y, Mizusawa J, Sumi M, Kinoshita M, Nagane M, Arakawa Y, Yoshimoto K, Shibahara I, Shinojima N, Asano K, Tsurubuchi T, Sasaki H, Asai A, Sasayama T, Momii Y, Sasaki A, Katayama H, Fukuda H : Randomized phase III study of high-dose methotrexate and whole brain radiotherapy with or without concomitant and adjuvant temozolomide in patients with newly diagnosed primary central nervous system lymphoma : JCOG1114C.J Clin Oncol 38 (15 suppl) : 2500, 2020.

25) Morris PG, Correa DD, Yahalom J, Raizer JJ, Schiff D, Grant B, Grimm S, Lai RK, Reiner AS, Panageas K, Karimi S, Curry R, Shah G, Abrey LE, DeAngelis LM, Omuro A : Rituximab, methotrexate, procarbazine, and vincristine followed by consolidation reduced-dose whole-brain radiotherapy and cytarabine in newly diagnosed primary CNS lymphoma : final results and long-term outcome. J Clin Oncol 31:3971-3979, 2013.

26) Narita $Y$, Nagane M, Mishima K, Terui Y, Arakawa Y, Yonezawa H, Asai K, Fukuhara N, Sugiyama K, Shinojima N, Kitagawa J, Aoi A, Nishikawa R: Phase I/II study of tirabrutinib, a second-generation Bruton's tyrosine kinase inhibitor, in relapsed/refractory primary central nervous system lymphoma. Neuro Oncol $23: 122-133,2021$.
27) Owen C, Berinstein NL, Christofides A, Sehn LH : Review of Bruton tyrosine kinase inhibitors for the treatment of relapsed or refractory mantle cell lymphoma. Curr Oncol 26 : e233-e240, 2019.

28) Rubenstein J, Ferreri AJ, Pittaluga S : Primary lymphoma of the central nervous system : epidemiology, pathology and current approaches to diagnosis, prognosis and treatment. Leuk Lymphoma 49 Suppl 1: 43-51, 2008.

29) Sakata A, Okada T, Yamamoto A, Kanagaki M, Fushimi Y, Dodo T, Arakawa Y, Takahashi JC, Miyamoto S, Togashi K : Primary central nervous system lymphoma : is absence of intratumoral hemorrhage a characteristic finding on MRI? Radiol Oncol 49: 128-134, 2015.

30) Seki R, Ohshima K, Fujisaki T, Uike N, Kawano F, Gondo H, Makino S, Eto T, Moriuchi Y, Taguchi F, Kamimura T, Tsuda H, Ogawa R, Shimoda K, Yamashita K, Suzuki K, Suzushima H, Tsukazaki K, Higuchi M, Utsunomiya A, Iwahashi M, Imamura Y, Tamura K, Suzumiya J, Yoshida M, Abe Y, Matsumoto T, Okamura T: Prognostic impact of immunohistochemical biomarkers in diffuse large B-cell lymphoma in the rituximab era. Cancer Sci $100: 1842-1847,2009$.

31) van der Meulen M, Bromberg JEC, Lam KH, Dammers R, Langerak AW, Doorduijn JK, Kros JM, van den Bent MJ, van der Velden VHJ : Flow cytometry shows added value in diagnosing lymphoma in brain biopsies. Cytometry B Clin Cytom 94: 928-934, 2018.

32) Wilson WH, Young RM, Schmitz R, Yang Y, Pittaluga S, Wright G, Lih CJ, Williams PM, Shaffer AL, Gerecitano J, de Vos S, Goy A, Kenkre VP, Barr PM, Blum KA, Shustov A, Advani R, Fowler NH, Vose JM, Elstrom RL, Habermann TM, Barrientos JC, McGreivy J, Fardis M, Chang BY, Clow F, Munneke B, Moussa D, Beaupre DM, Staudt LM : Targeting $\mathrm{B}$ cell receptor signaling with ibrutinib in diffuse large B cell lymphoma. Nat Med 21: 922-926, 2015.

33) Woyach JA, Furman RR, Liu TM, Ozer HG, Zapatka M, Ruppert AS, Xue L, Li DH, Steggerda SM, Versele M, Dave SS, Zhang J, Yilmaz AS, Jaglowski SM, Blum KA, Lozanski A, Lozanski G, James DF, Barrientos JC, Lichter P, Stilgenbauer S, Buggy JJ, Chang BY, Johnson AJ, Byrd JC : Resistance mechanisms for the Bruton's tyrosine kinase inhibitor ibrutinib. N Engl J Med 370 : 2286-2294, 2014.

34) Yamasaki F, Kurisu K, Satoh K, Arita K, Sugiyama K, Ohtaki M, Takaba J, Tominaga A, Hanaya R, Yoshioka H, Hama S, Ito Y, Kajiwara Y, Yahara K, Saito T, Thohar MA : Apparent diffusion coefficient of human brain tumors at MR imaging. Radiology 235: 985-991, 2005.

35) Yamasaki F, Takayasu T, Nosaka R, Amatya VJ, Doskaliyev A, Akiyama Y, Tominaga A, Takeshima Y, Sugiyama K, Kurisu $\mathrm{K}$ : Magnetic resonance spectroscopy detection of high lipid levels in intraaxial tumors without central necrosis : a characteristic of malignant lymphoma. J Neurosurg $\quad 122: 1370^{-}$ 1379, 2015.

36）山崎文之, 高安武志, 杉山一彦: 中枢神経系原発悪性リ ンパ腫。杉山一彦，橋本直哉編：脳神経外科速報 2020 年 増刊 悪性脳腫瘍のすべて. 大阪, メディカ出版, 2020, pp.251-258. 
中枢神経系原発リンパ腫アップデート

山崎 文之

中枢神経系原発リンパ腫（PCNSL）は高齢者に多く発生し，近年増加傾向にあり，脳腫湯の $4.9 \%$ を占める. びまん性大細胞型の組織型が多く, その中では non-GCB typeが多い. PCNSLではMYD88 と CD79B の变異の頻度が高く, BCR シグナル伝達経路の活性化が起こっているため, その経路にあ る BTK 阻害剤のチラブルチニブが再発・難治の PCNSL の治療薬として開発された. 放射線照射後の 脳障害の軽減 • 回避と高齢者に対する治療が課題で, 治療成績の向上には新しい標準治療とされる $\mathrm{R}-$ MPV 療法の普及や若年患者での末梢血幹細胞移植を伴う大量化学療法, そして再発時の適切な治療 選択が肝要である.

脳外誌 $31 ： 20-30,2022$ 